\title{
Sesotho Language
}

National Cancer Institute

\section{Source}

National Cancer Institute. Sesotho Language. NCI Thesaurus. Code C154127.

A Niger-Congo Bantu language spoken in South Africa and in Lesotho, where it is the national language. 